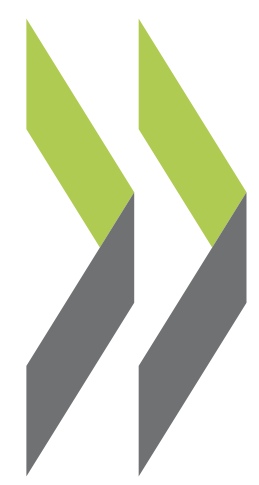

OECD Economics Department Working Papers No. 1095

Green Growth Challenges and the Need for an Energy

Carla Valdivia de Richter Reform in Mexico 


\section{Unclassified}

ECO/WKP(2013)87

Organisation de Coopération et de Développement Économiques

Organisation for Economic Co-operation and Development

12-Nov-2013

ECONOMICS DEPARTMENT

English - Or. English

GREEN GROWTH CHALLENGES AND THE NEED FOR AN ENERGY REFORM IN MEXICO

ECONOMICS DEPARTMENT WORKING PAPERS No. 1095

By Carla Valdivia de Richter

All Economics Department Working Papers are available through OECD's Internet website at www.oecd.org/eco/Workingpapers

JT03348304

Complete document available on OLIS in its original format

This document and any map included herein are without prejudice to the status of or sovereignty over any territory, to the delimitation of international frontiers and boundaries and to the name of any territory, city or area. 


\section{ABSTRACT/RESUMÉ \\ Green growth challenges and the need for an energy reform in Mexico}

As Mexico seeks to boost economic growth, pressures on its natural resources and environmental outcomes may intensify, jeopardizing the sustainability of that growth and the well-being of the population. Costs of environmental degradation were estimated at approximately 5\% of GDP in 2011, primarily from the health impact of air pollution, while overexploitation of natural resources - such as water - threatens their sustainability. Subsidies and prices do not reflect environmental externalities or cost of providing natural resources, including scarcity costs. They result in poor environmental outcomes, represent a heavy burden on the government budget and, contrary to their original objective, have not efficiently tackled poverty and inequality. Such subsidies should be gradually removed. In the energy sector, reforms are needed in order to allow the state-owned oil company PEMEX to become more efficient operationally and environmentally, and to better provide fiscal revenues.

JEL classification: H23, O44, Q5, Q4.

Keywords: Mexico, green growth, climate change, water sustainability, energy.

\section{Les défis de la croissance verte et la nécessité d'une réforme de l'énergie au Mexique}

Comme le Mexique cherche à stimuler la croissance économique, les pressions sur les ressources naturelles et les effets sur l'environnement peuvent s'intensifier, ce qui compromet la durabilité de cette croissance et le bien-être de la population. Les coûts de la dégradation de l'environnement ont été estimés à environ 5\% du PIB en 2011, essentiellement dus à l'impact sanitaire de la pollution de l'air, tandis que la surexploitation des ressources naturelles - comme l'eau - menace leur pérennité. Les subventions et les prix ne reflètent pas les externalités environnementales ou le coût de l'approvisionnement de ressources naturelles, y compris les coûts de rareté. Elles se traduisent par des résultats médiocres pour l'environnement, représentent un lourd fardeau pour le budget de l'État et, contrairement à leur objectif initial, n'ont pas été très efficace contre la pauvreté et l'inégalité. Ces subventions devraient être progressivement supprimées. Dans le secteur de l'énergie, des réformes sont nécessaires afin de permettre à la compagnie pétrolière publique PEMEX de devenir plus efficace sur le plan opérationnel et de l'environnement, et à améliorer la prestation des recettes fiscales.

JEL classification: H23, O44, Q5, Q4.

Mots clés : Mexique, croissance verte, changement climatique, durabilité de l'eau, énergie. 


\section{TABLE OF CONTENTS}

Green growth challenges and the need for an energy reform in Mexico …......................................... 5

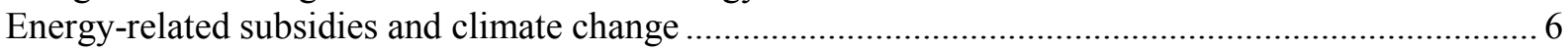

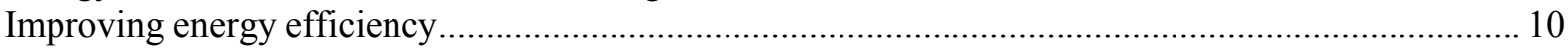

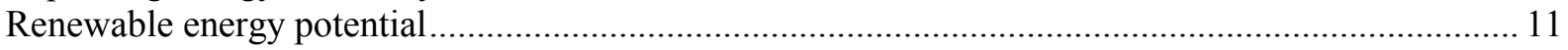

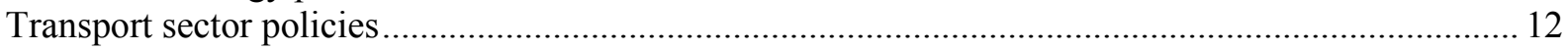

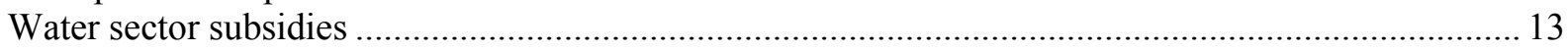

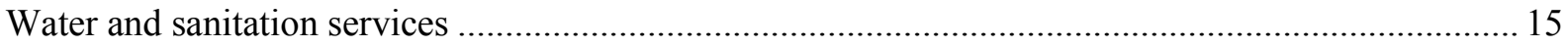

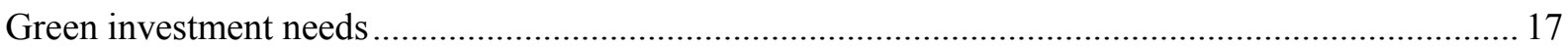

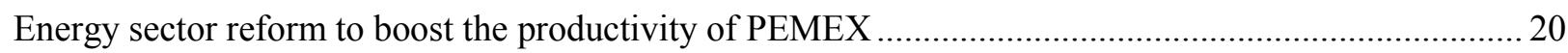

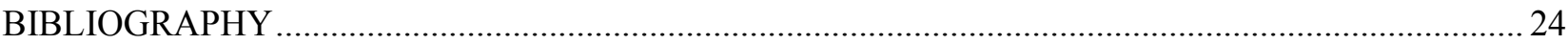

\section{Tables}

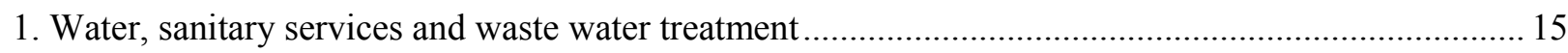

\section{Figures}

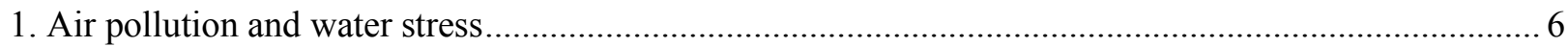

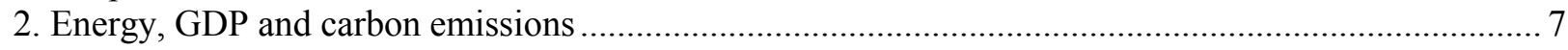

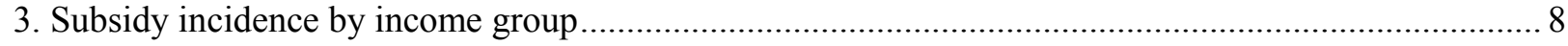

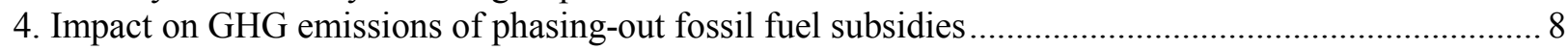

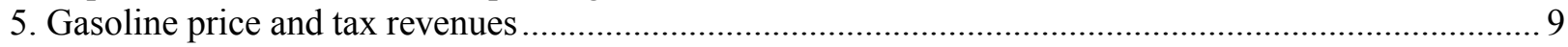

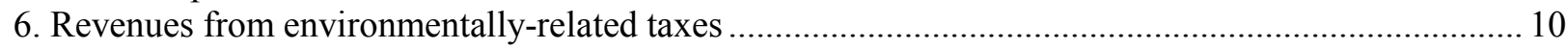

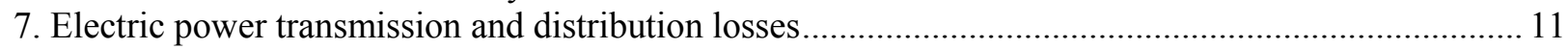

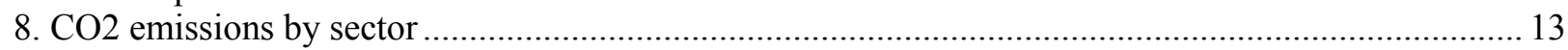

9. CONAGUA's budget and revenues from water abstraction charges ................................................ 14

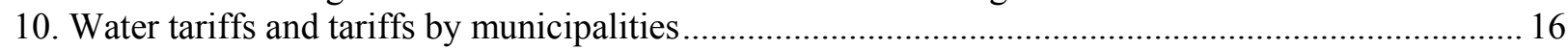

11. Investments required to 2030 in low-carbon interventions in Mexico by sector ............................. 18

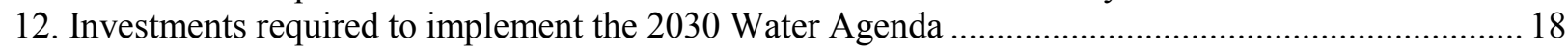

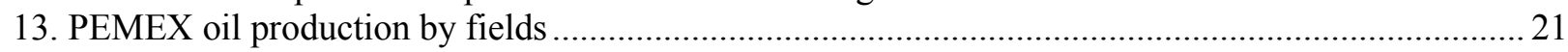

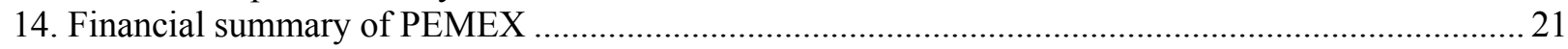

\section{Boxes}

1. Attracting private investment towards green infrastructure through structured instruments (CKDs)...20

2. Main recommendations for green growth and energy policy ........................................................23

The statistical data for Israel are supplied by and under the responsibility of the relevant Israeli authorities. The use of such data by the OECD is without prejudice to the status of the Golan Heights, East Jerusalem and Israeli settlements in the West Bank under the terms of international law. 
ECO/WKP(2013)87 
ECO/WKP(2013)87

\title{
GREEN GROWTH CHALLENGES AND THE NEED FOR AN ENERGY REFORM IN MEXICO
}

\author{
by Carla Valdivia de Richter ${ }^{1}$
}

Over the last decade, Mexico has shown high commitment to green growth challenges by strengthening its national environmental policies and showing strong leadership at an international level in areas such as climate change and water management. At the beginning of this year, the new government created an inter-ministerial commission to address climate change with the aim of defining a common agenda and creating guidelines for a state policy to address climate change in a timely and effective manner. This effort to improve coherence for climate change-related policies is to be commended, and the approach can be applied to policies that affect the environment even more broadly. Implementing such policies in an effective and efficient manner is a key challenge. For instance, although air quality has generally improved in the last decade, air pollution still accounts for three-quarters of costs of environmental degradation, estimated at approximately 5\% of GDP in 2011 (INEGI, 2013). Some Mexican cities are among the most polluted cities in the world (Figure 1, Panel A). In addition, the country's water use is not sustainable as 101 of the 653 aquifers are overdrawn, especially in the northern and northwest areas, where three-quarters of the population live, and both surface and ground water quality are threatened by pollution (Figure 1, Panel B).

1. Economics Department, OECD, email: carla.valdivia@oecd.org. This paper was originally produced for the 2013 OECD Economic Survey of Mexico, which was published in May 2013 under the authority of the Economic and Development Review Committee (EDRC) of the OECD. Compared to the Survey, it has been updated. I would like to thank the useful comments from Andrew Dean, Robert Ford, Patrick Lenain, Sean Dougherty, Nicola Brandt, Frédérique Zegel, Celine Kaufman, Aziza Akhmouch, Xavier Leflaive and members of the EDRC for valuable comments and discussions. I am also grateful to Roselyne Jamin and Valerie Dugain for technical assistance and to Heloise Wickramanayake for secretarial assistance. This paper contains the views of the author, and not necessarily those of the OECD or its member countries; nor the Central Bank of Chile or its board members (Carla Valdivia is seconded to the OECD from the Central Bank of Chile). 
Figure 1. Air pollution and water stress

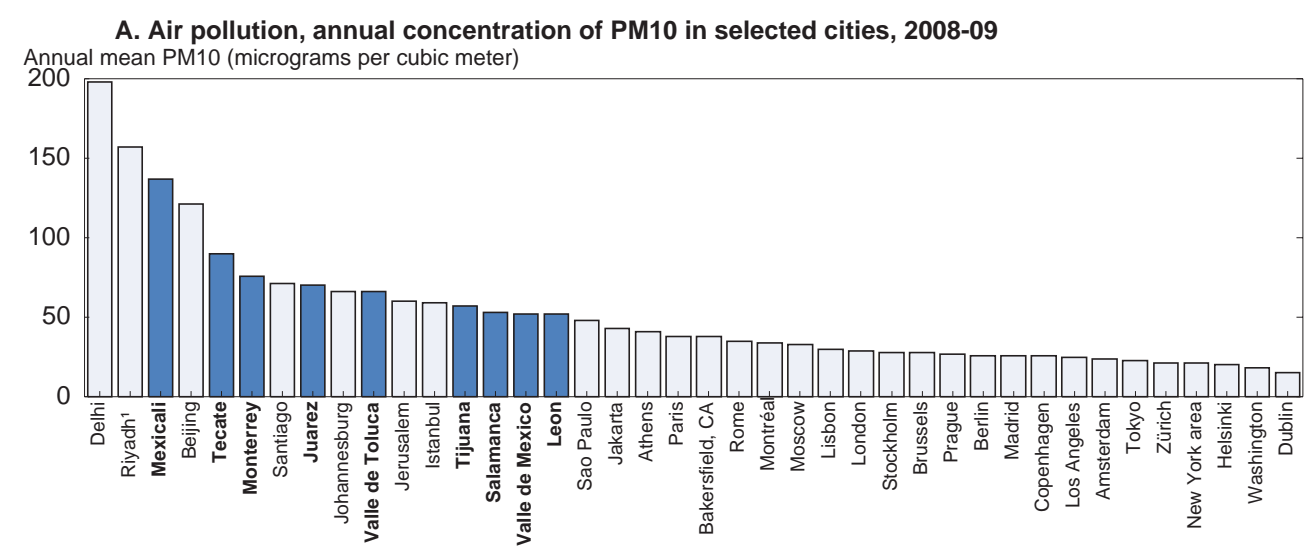

B. Water stress and water availability by river basin

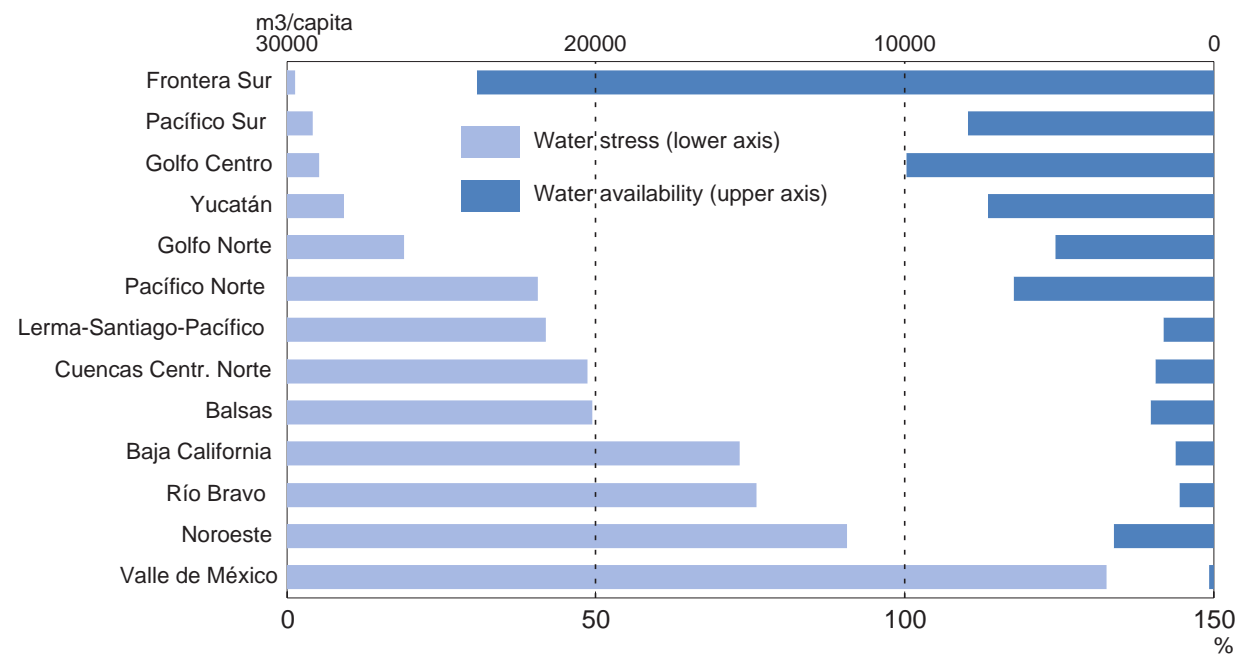

1. Last available data 2003.

Source: WHO, Urban outdoor air pollution database; CONAGUA.

Green growth challenges in Mexico are closely connected to policies in the energy, electricity, transport and water sectors, where pricing does not reflect the costs of providing environmental goods, let alone externalities. There has been insufficient reform. This paper focuses on green growth policies related to such sectors with the focus on subsidies and environmental taxes. It also covers the main problems faced by the state-owned oil company PEMEX and much-needed reforms to improve its operational and environmental efficiency in order to become an effective contributor of fiscal revenues. Other policy areas, such as biodiversity, forestry, agriculture and waste management, are extensively covered in the recent 2013 Environmental Performance Review of Mexico (OECD, 2013c).

\section{Energy-related subsidies and climate change}

Mexico faces considerable environmental pressure. Estimates show that $68 \%$ of the population and $71 \%$ of GDP are highly exposed to climate-change risks (SEMARNAT, 2009), affecting mainly agriculture production, water availability, deforestation, biodiversity and health. Reducing greenhouse gas (GHG) emissions remains a major challenge, particularly since Mexico contributes over $1 \%$ of global GHG emissions and had the weakest performance in the OECD in decoupling $\mathrm{CO}_{2}$ emissions from 
economic growth from 2000 to 2010 (Figure 2). $\mathrm{CO}_{2}$ emissions from energy use have increased by 19\% during the last decade which in part is due to the fact that most energy production depends on fossil fuels $(89 \%)$ which are highly subsidised. Energy-related emissions account for almost three-quarters of total GHG emissions.

Figure 2. Energy, GDP and carbon emissions ${ }^{1}$
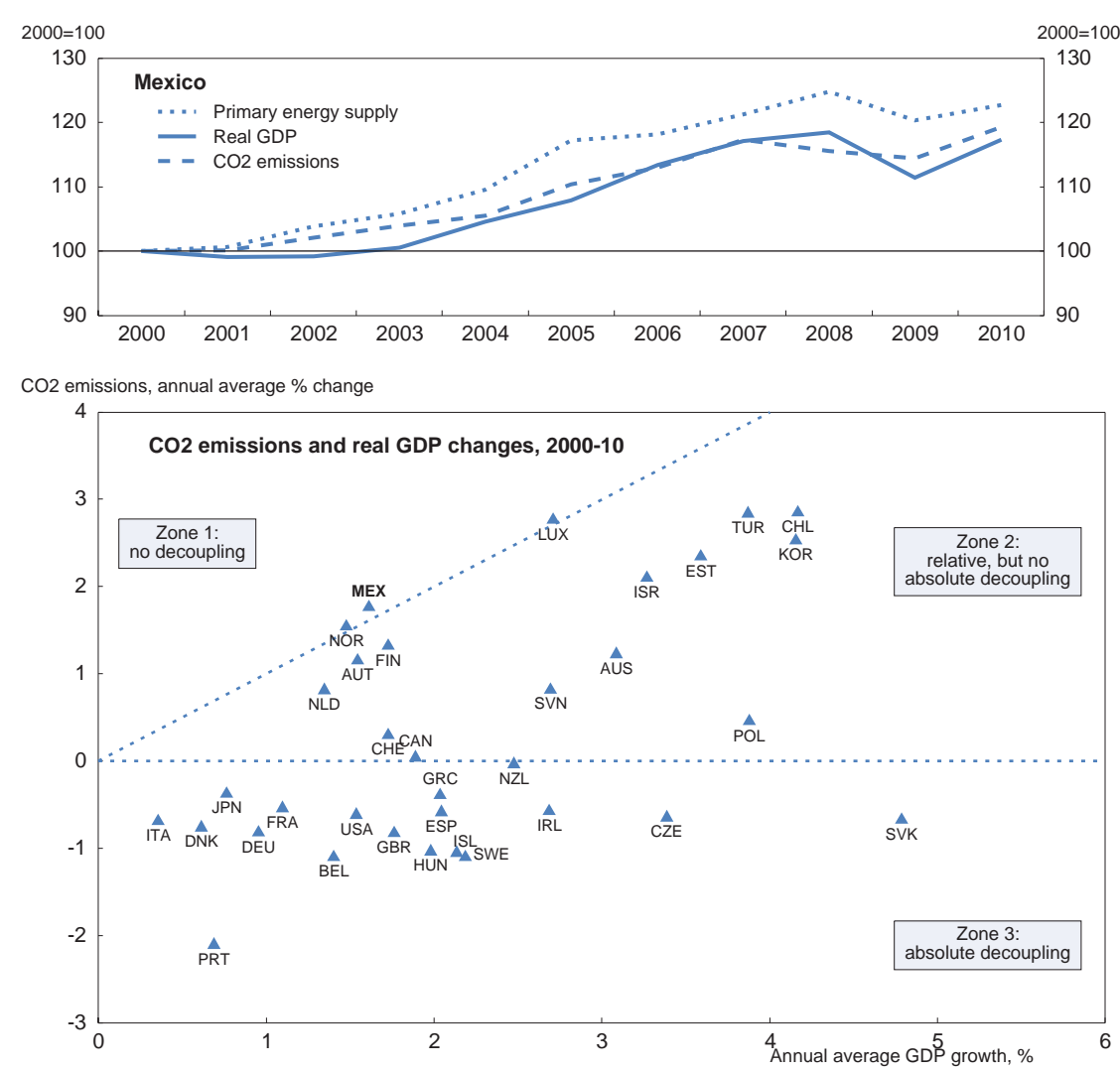

1. $\mathrm{CO}_{2}$ emissions from fuel combustion. Sectoral approach.

Source: OECD (2013a); IEA.

Electricity use in the agricultural and residential sectors is subsidised by reduced tariffs, whereas petrol and diesel are indirectly subsidised in times of high and rising international prices, as the government applies a price-smoothing mechanism to local prices. Overall, fossil-fuel subsidies (including gasoline and electricity) averaged 1.7\% of GDP during the period 2006-12, encouraging inefficient and excessive energy use and weighting on public finances. Though intended to address social concerns, those subsidies disproportionately benefit the wealthiest population groups (Figure 3). 
Figure 3. Subsidy incidence by income group
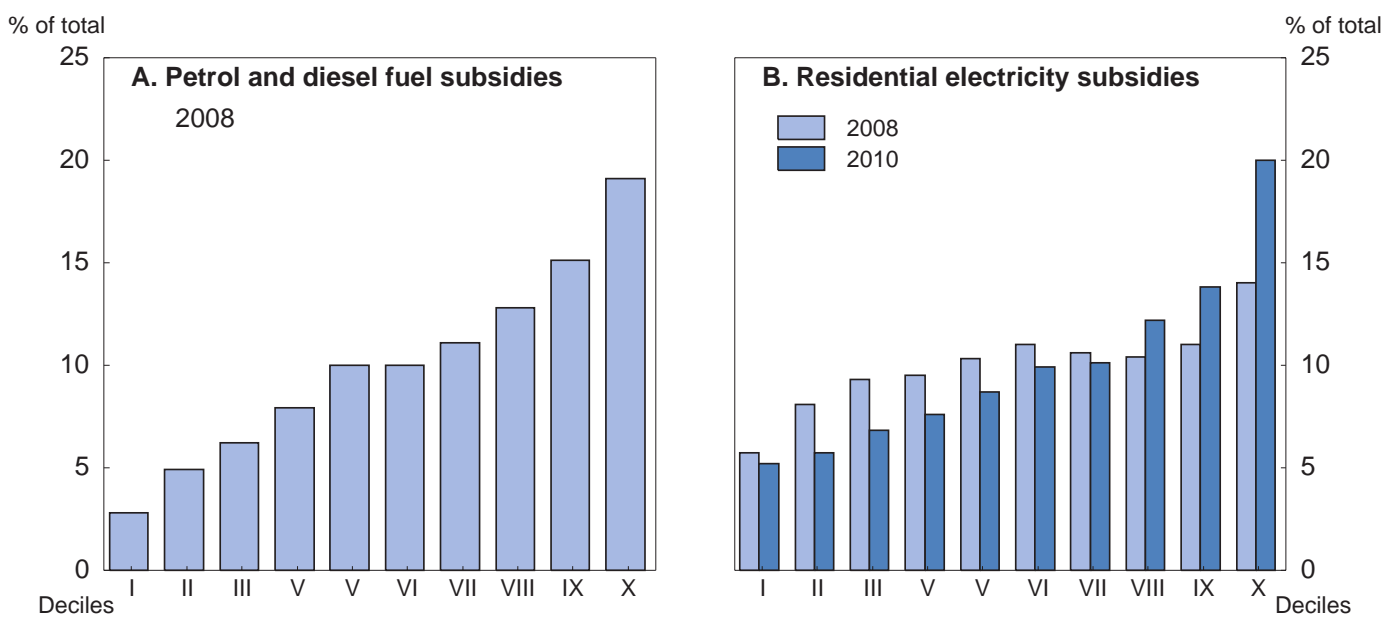

Source: Ministry of Finance and Public Credit.

The country has set ambitious emission reduction targets, including greater use of renewables. This was confirmed in its recent General Law on Climate Change, with the target of reducing GHG emissions $30 \%$ below a business-as-usual scenario by 2020 and $50 \%$ by 2050 from the 2000 level, conditional on international financial support. It also set the target of increasing electricity from non-fossil fuels from current $20 \%$ to $35 \%$. Fully removing subsidies and introducing carbon prices, either with excise taxes or through a trading system, is the first and most cost-efficient way to accomplish these goals, since by themselves, these policies would ensure that households, industries and farmers exploit the least-cost strategies to reduce emissions. It would also stimulate opportunities for obtaining private sector support to finance investments in energy efficiency, renewable energy and other green infrastructure and technology. OECD simulations indicate that phasing out fossil-fuel consumption subsidies in Mexico could reduce GHG emissions (excluding land-use change related emissions) by $10 \%$ by 2050 , compared with businessas-usual (OECD, 2012c) (Figure 4). However, such measures should be accompanied by an effective communication campaign to overcome reform resistance.

Figure 4. Impact on GHG emissions ${ }^{1}$ of phasing-out fossil fuel subsidies

$\ln 2050$

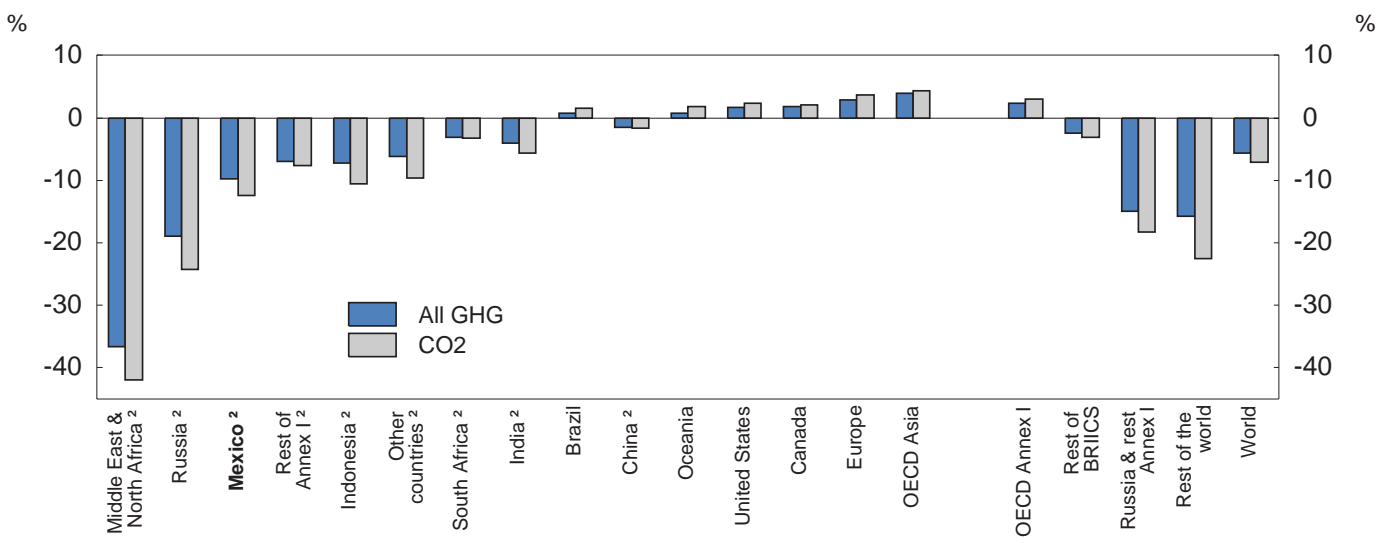

1. Excludes emissions from land-use change.

2. Regions/countries for which fossil fuel subsidies reform is simulated. Annex I refers to countries of the Kyoto Protocol.

Source: OECD ENV-Linkages model using IEA fossil-fuel subsidies data (OECD, 2012c). 
To address poverty and inequality, the savings from these subsidies could be used to fund direct cash transfers by further expanding Oportunidades which has proved to be effective for targeting poor families. The policy of raising gasoline prices by 9 MXP cents per month, and from January 2013, by 11 cents per month is an important step in closing the gap between Mexican and United States' fuel prices. However, this still implies a significant implicit subsidy at current prices which will be eliminated only gradually, unless international prices fall. Thus, more determined action may be warranted to phase out these high and environmentally harmful subsidies (Figure 5). Once the subsidy disappears, establishing a positive excise tax and shifting towards a market-determined gasoline price that incorporates a carbon tax would be a positive step. This could be done gradually by using a transitory, rule-based smoothing mechanism.

Figure 5. Gasoline price and tax revenues

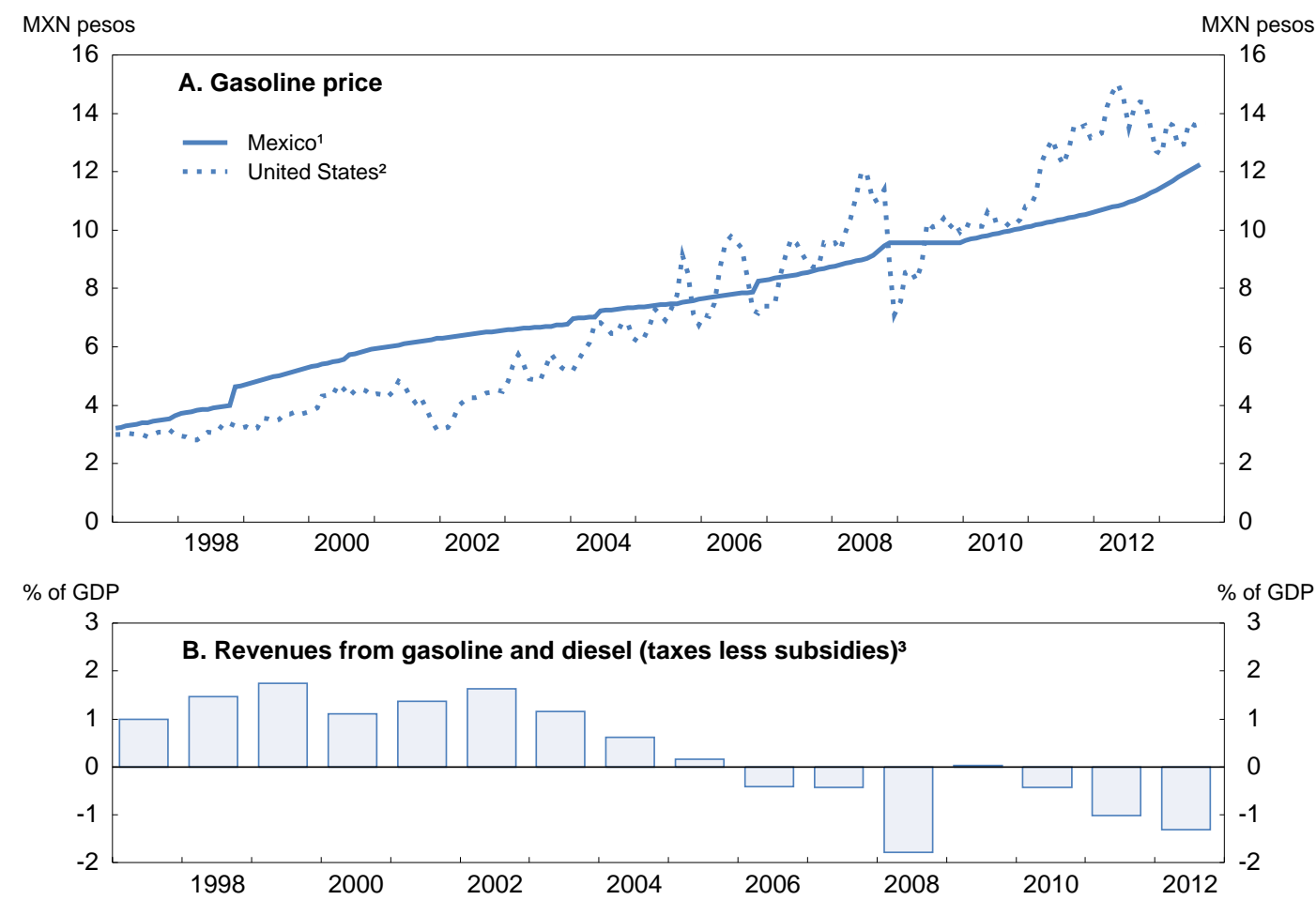

1. Premium gasoline price, end-of-period.

2. U.S. Premium Reformulated Retail Gasoline Prices.

3. Tax to gasoline and diesel (IEPS de gasolinas $y$ diesel) which in times of high and rising international prices becomes negative (subsidy), as the government applies a price-smoothing mechanism to local prices. Preliminary data for 2012.

Source: INEGI; SHCP; Energy Information Administration; OECD, Main Economic Indicators database.

Electricity subsidies for agriculture and residential sectors account for more than two-thirds of the cost of providing electricity to these sectors. They are among the largest in the world and have increased over recent decades, linked partly to the high costs of energy provision. These subsidies, together with other programmes supporting the agricultural sector, account for a large part of the sector's public spending being among the highest in Latin America and in OECD countries (OECD 2013c).

Together with removing energy subsidies, using market-based instruments such as broad-based GHG emission taxes or an emission trading system (ETS) would be a good start to price emissions in line with their social costs. Taxes are perhaps easier to implement, because an infrastructure for them is already in place. Environmentally-related taxes have effectively been subsidies in recent years, as a result of the 
price-smoothing mechanism for fossil-fuels (Figure 6). There is considerable scope to raise higher revenues from these taxes. On the other hand, as discussed in the 2011 Economic Survey of Mexico, to some extent participating in ETSs may be more attractive for Mexico than raising carbon taxes, as it opens opportunities to obtain funds from abroad to finance investments in energy efficiency (OECD, 2011a).

Figure 6. Revenues from environmentally-related taxes ${ }^{1}$

In 2010

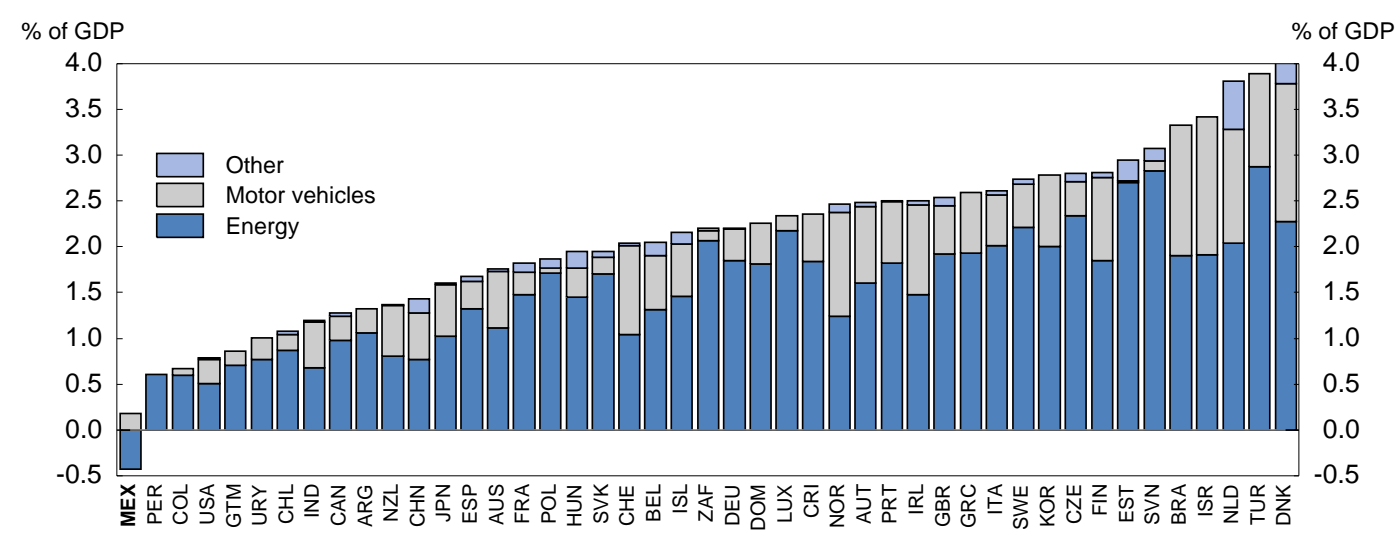

1. In Mexico, fluctuations of consumer prices on motor vehicle fuels are smoothed out. In 2010 , when world market prices were particularly high, the excise tax on fuels turned into a subsidy, equalling approximately $0.5 \%$ of GDP.

Source: OECD/EEA database on instruments used for environmental policy and natural resources management, www.oecd.org/env/policies/database.

An opportunity for Mexico to join in the regional ETS in North America exists now that California's trading system has begun operating. With cheaper abatement possibilities, Mexico can sell emission rights to its northern neighbours, raising funds for financing investments in emission reductions. The country has expressed clear interest to participate in these carbon markets and has established the basis in its General Law on Climate Change to implement a domestic trading system with the possibility to link it to other countries. Another opportunity would be to use the experience from PEMEX's past voluntary internal ETS implemented in the first half of the 2000s, which could be revived and extended, first in the electricity sector and then gradually in other key industries.

However, implementation of emissions taxes and trading schemes is subject to various challenges. First the electricity and oil sectors are dominated by state-owned monopolies in Mexico, whose incentives for output reduction in response to higher emission costs are lower than in a competitive market. Given complex financial relationships with the central government, these companies' budget constraints are likely to be soft and many incentives distorted. This also applies to incentives to invest in new energy-efficient technologies. Therefore, carbon prices may have to be accompanied with instruments that are not marketbased, such as further technology standards and regulation, unless Mexico improves the governance of its state-owned companies and allows more competition in these sectors. Furthermore, the presence of federal, state and municipal governments in environmental policymaking adds another layer of complexity to enforcement. Finally, the private sector is likely to resist policy measures that may affect competitiveness vis-à-vis China, for instance.

\section{Improving energy efficiency}

Complementary regulatory changes would improve energy efficiency and reduce emissions while subsidies are being gradually removed. There is potential for energy efficiency improvements in the energy 
sector as well as for end-users. Mexico should identify and implement more cost-effective approaches for further improving energy efficiency.

Electricity transmission and distribution losses in Mexico are about twice international averages placing them among the highest in OECD countries (Figure 7). Investment in this kind of infrastructure is crucial as the country could benefit from leapfrogging old technologies to new ones. In the energy sector, particularly regarding the state-owned oil and gas (PEMEX) and electricity (CFE) companies, new investments need to take into account externalities and incorporate new, more efficient and cleaner technologies. Abatement measures such as the reduction of gas flaring, increased efficiency of installation and co-generation installations have been implemented in the last years, following the energy efficiency objectives in the National Energy Strategy and regulations implemented by the National Hydrocarbon Commission. Though results have been positive and targets were accomplished, more needs to be done and cost-effectiveness of these measures still need to be evaluated, particularly given the financial constraints that these state-owned companies face.

Figure 7. Electric power transmission and distribution losses

Per cent of output, 2007-09

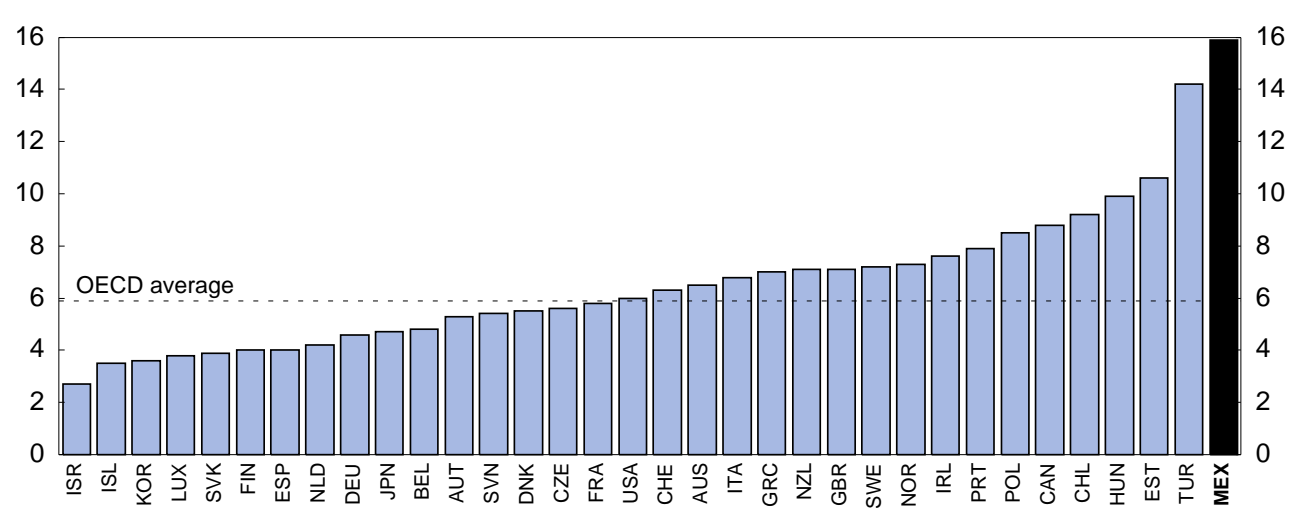

Source: IEA, Electricity Information Statistics database.

For end-use sectors the main programme for tapping energy efficiency has been PRONASE, which has set the target of reducing electricity demand by up to $18 \%$ by 2030 through subsidy-based instruments. These instruments include soft loans, tax deductions for environment-related investments, zero tariffs on imports of pollution control equipment, tax credits for scrapping buses and heavy vehicles, subsidies to replace old home electric appliances and loans to low-income households for purchases of energy efficient houses. Of particular success was the programme Luz Sustentable with the purpose of replacing, with no cost to the individual household, incandescent light bulbs with energy saving bulbs. Though these programmes in general have generated energy savings, such measures are less efficient than price instruments, such as taxes, because they imply a large cost to the budget, discriminate against households and businesses with limited access to such investments, and they can force the adoption of the subsidised solutions even if there are other solutions that are more effective. Such incentives would be less warranted if subsidies to energy were removed.

\section{Renewable energy potential}

Given current price signals, it will be very challenging to reach Mexico's ambitious emission reduction targets, which include increasing electricity from non-fossil fuels from the current $20 \%$ to $35 \%$ by 2024 . The share of renewables in electricity production declined between 2000 and 2011, and non- 
hydro renewable energy declined from $3.7 \%$ to $3.3 \%$ over the same period. However, Mexico has large potential for developing renewable energy due to its physical and climatic conditions. As an example, according to government estimates wind energy potential is over $50 \mathrm{GW}$ compared to current capacity of only $1.2 \mathrm{GW}$. Total electricity capacity in 2011 reached $61.8 \mathrm{GW}$.

Measures to increase electricity prices for industry and technological developments have resulted in a significant expansion of wind power the last six years. However, it has been mainly for private selfgeneration, given the current regulation which allows private sector participation in power generation, but can only sell its surplus to the state-owned electricity company CFE. Given that CFE buys energy at the least-cost price with no consideration for environmental externalities, much renewable-based power cannot be competitive. A revision of CFE's cost-based planning to account for externalities has been concluded in 2012 and is a welcomed step.

Over the past decade, Mexico has undertaken several projects to overcome barriers to renewables. Since the mid-2000s, large wind projects co-financed by grants from the Global Environment Facility and World Bank loans have proved successful for building capacity in grid-connected renewable applications. New regulatory instruments have been put in place, including an energy bank allowing self-suppliers to carry over excess capacity from one year to the next; lower capacity back-up fees levied on self-supply generators and new bidding mechanisms for the private sector to cover the costs of new CFE grid capacity. In addition, since 2005, the Federal Income Tax Law has allowed 100\% depreciation of capital expenses for renewables in a single year (OECD, 2013c).

These measures, combined with other programmes such as further developing the grid and its access from renewable energy producers, addressing land compensation issues, tackling complicated permitting procedures and building a national renewable energy inventory, could allow greener energy to develop in the future, especially wind and solar. Commitments from the new government in the Pact include gradually doubling investment in R\&D from its current of about $1 / 2$ per cent of GDP, and reducing dependence on fossil-fuels by investing in R\&D in renewable energy sources such as wind and solar. This is highly welcomed.

Non market-based instruments, such as feed-in-tariffs used in Portugal to incentivise technology clusters in wind and solar power (OECD, 2011b), could be introduced as a second-best option to allow some time for gradual cost reductions of renewable energy, but after that, they should be phased out. Mexico might be able to develop a whole new sector by seizing these opportunities, while improving access to basic infrastructure.

\section{Transport sector policies}

The transport sector is a major and expanding source of $\mathrm{CO}_{2}$ emissions, driven by increased road transport and rapidly increasing motorization rates (Figure 8). Subsidies to gasoline and diesel through the price-smoothing mechanism as well as other incentives, such as low vehicle taxes, low standard enforcements and tax credits on road tolls to transport businesses, have reduced incentives to improve energy efficiency in the sector. These policies have run counter to a shift to smaller, more efficient and lower emission vehicles. Vehicle taxes that vary according to environmental performance or environmental standards are only applied in a few states, including the important case of Mexico City. The annual tax on vehicle ownership or use (tenencia) has been transferred from the Federal Government to the States in 2012, but fewer than half of the States have implemented these taxes due to weak political incentives (see Chapter 3 of the 2013 Mexico Economic Survey) (OECD, 2013d). 
Figure 8. $\mathrm{CO} 2$ emissions by sector

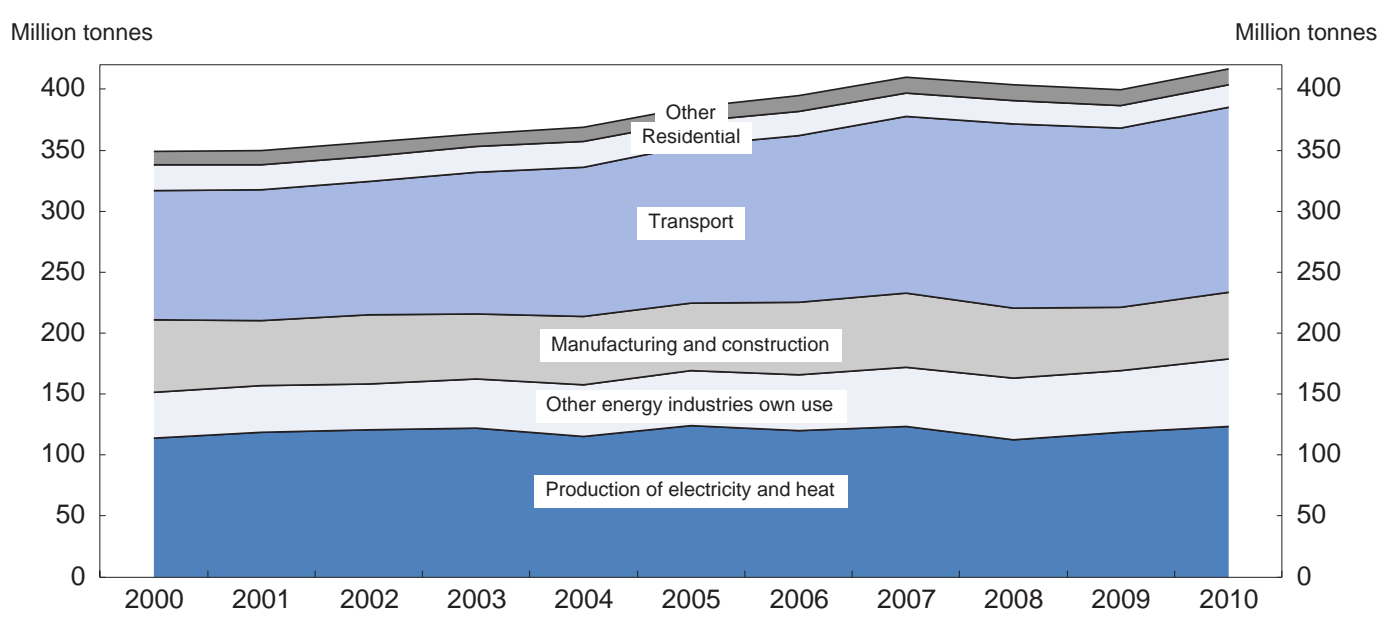

Source: OECD-IEA (2012), CO2 Emissions from Fuel Combustion.

Mexico also levies a one-off tax on every purchase of a new passenger vehicle. New electric and hybrid cars are exempted, yet such vehicles still represent a minor share of the market, suggesting that this exemption has had limited impact. Restructuring vehicle taxes on all cars so that they take into account environmental performance can incentivise the use of more energy-efficient vehicles. In addition, enforcing environmental standards, although not the most efficient solution, could also be used in the absence of political support for increasing taxes or removing fossil fuel subsidies. Current work of the National Commission of Energy Efficiency (CONUEE) to set efficiency rules for new and imported used vehicles is a step in this direction. However, even enforcing environmental car standards has been difficult and faces strong opposition from car companies. Mexico should broaden the application of the annual tax (tenencia) to all states and restructure vehicle taxes to take into account more directly environmental performance. Direct taxes on fuel consumption are the most efficient option given that they are more directly linked with carbon emissions; however, other environmental policy instruments such as vehicle taxes and standards could be complementary.

Directing public and private investment into low-carbon public transport and developing programmes to promote sustainable urban transport could reduce pollution, improve the well-being of the population through lower health costs related to respiratory illness, and result in time savings by reducing congestion. The implementation of urban public transport such as the Bus Rapid Transit (BRT) system that is present in more than 10 cities, including Mexico City, and other mass transit projects lead by the federal programme PROTRAM, are good examples of public and private investment in environmentally friendly infrastructure, having generated strong environmental, social and economic benefits (Francke et al., 2012). However, public transport projects and urban development should be based on strategic master plans, integrating transport and land-use planning, with clear policy goals and ex-ante cost-benefit analysis that consider climate-change and other environmental costs. A federal law for public transportation could be a solution to address the problems of different priorities at different governing levels. Work has also started by the OECD with Mexico to review urban policies with the aim of recommending multi-sectoral comprehensive urban policy advice that might maximise economic efficiency and foster sustainable urban development and social cohesion.

\section{Water sector subsidies}

Mexico's current water use is not sustainable. One hundred and one of the country's 653 aquifers are overdrawn, many of which are in the northern and northwest areas, where three-quarters of the population 
lives, and both surface and groundwater quality are threatened by pollution. Poor water quality, low stream flows, the drying up of wetlands and the intrusion of salt water into groundwater are some of the consequences. This threatens the health of ecosystems and humans; scarcity and pollution add costs to the provision of water, as it has to be treated before it can be used, and they are a major constraint for agricultural productivity with negative implications for economic development. Moreover, water pressures might become even more pronounced as climate change progresses, since Mexico is expected to experience increasing temperatures, reduced rainfall and increased incidence of extreme weather events (World Bank, 2011). Although access to water services has increased substantially, there are still 11 million Mexicans who lack access to piped water and 14.8 million with no access to sanitation services, with large differences between urban and rural areas. This has a negative impact on economic opportunities and well-being.

In 2011, the country launched an ambitious 2030 Water Agenda with a long term strategic vision for Mexico's water sector. It envisions the achievement of four policy goals by 2030: accomplish universal access to water services, balance supply and demand for water, improve the quality of water (clean water bodies) and reduce exposure to hydro-meteorological events (settlements safe from catastrophic floods). This was complemented with a policy framework for water resource management. However, policy implementation has been a major problem, with subsidies in energy and agriculture sectors that are in odds with water policy objectives, a deficient operation of river basin councils and a regulatory framework for water and sanitation services scattered across multiple sectors (OECD, 2013b).

Mexico has experimented with market-based instruments for water, using water service charges and abstraction and pollution charges, to reflect the value of the resource. However, their net effect has been minimal due to excessively low prices, low payment rates and exemptions. Water abstraction and administration charges are collected by the National Commission of Water (CONAGUA, 2011). They are applied to underground and superficial waters to be used in public water supply, agriculture, industry, thermoelectric power and hydropower. Even though irrigated agriculture accounts for $77 \%$ of water use, no water abstraction charges are applied for irrigation users within their allocated quota, and a low charge is applied for use beyond the quota. In addition, this is effectively non-binding due to poor monitoring and enforcement. Moreover, many utilities do not pay abstraction or pollution charges. Water users' contributions over the last five years averaged over $40 \%$ of total budget for the water sector (Figure 9).

Figure 9. CONAGUA's budget and revenues from water abstraction charges

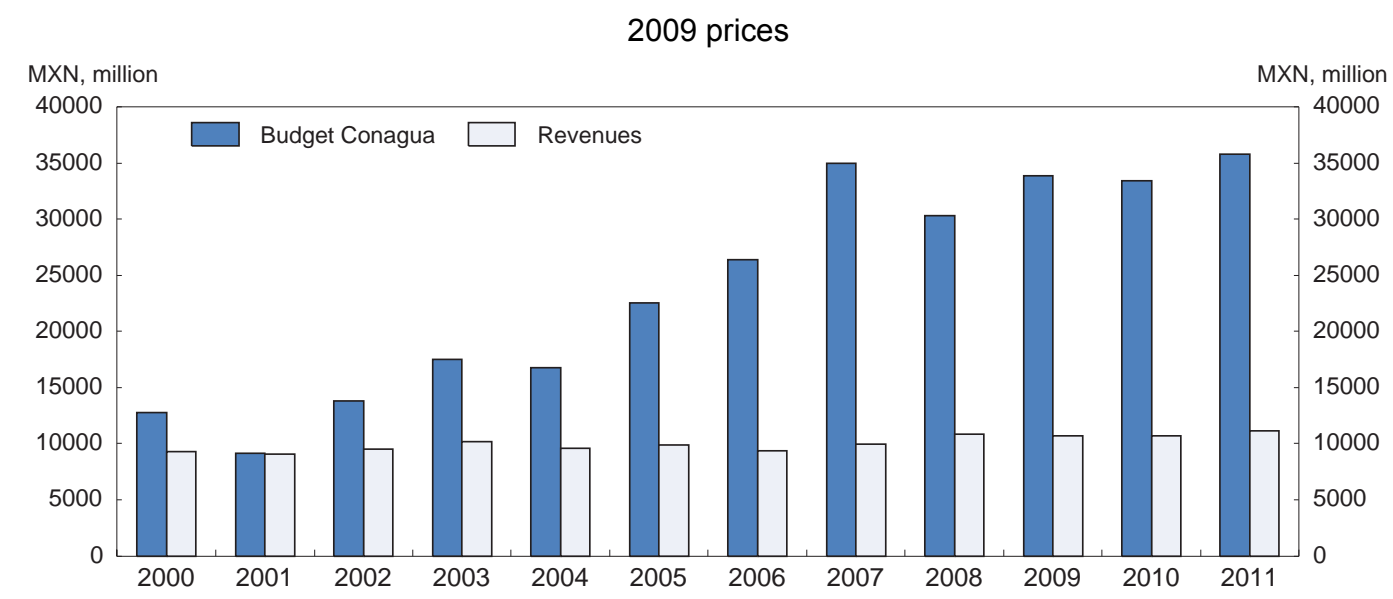

Source: CONAGUA; OECD (2013b). 
Subsidies to the agriculture sector, mainly through low electricity prices for pumping irrigation water (using subsidised Tarifa 09 and low or non-existent abstraction charges have provided limited incentives to improve efficiency of water use and reduce water losses. This has resulted in over-exploitation of ground water, discouraged investment in more efficient irrigation technologies and redirected water away from activities with a higher economic return. Estimations show that removing electricity subsidies with subsequent incentives to use more efficient technologies in agriculture would lead to a $15 \%$ reduction in water abstraction in the short term, and to a $19 \%$ reduction in the long term (OECD, 2013c). An additional problem is lack of enforcement which has resulted in high levels of under-reporting of consumption and illegal abstractions. Resources for monitoring water use account for less than $1 \%$ of CONAGUA's budget. Moreover, agricultural subsidies have proven to be regressive since the bulk of it benefits mostly the richest $10 \%$ of farmers and redirect water away from activities with higher economic return (OECD, 2013c).

Gradually removing electricity subsidies for pumping water for irrigation in agriculture and replacing them with cash transfers, independent of water use, as some pilot programmes have been doing, would promote a more sustainable use of water. In addition, reallocating more efficiently resources to monitoring, including the widening of water meters to better monitor water consumption would help charges to operate best and prevent waste.

\section{Water and sanitation services}

Access to basic water and sanitation services has been a national priority during the last decade, with investments having almost tripled. Water and sanitation coverage has increased considerably, now close to $92 \%$ of the population (Table 1). However, there is much to be done to accomplish universal access to water and reduce urban and rural differences. In addition, Mexico has the lowest rate of connection to public sewerage treatment in the OECD, with about $47 \%$ of collected municipal wastewater. Lack of access to utilities negatively impacts economic opportunities and well-being. When connections are available, households can engage in more productive activities and leisure, as well as expand market opportunities for business, increasing productivity and investment.

Table 1. Water, sanitary services and waste water treatment

Per cent

\begin{tabular}{|c|c|c|c|c|c|}
\hline & 1990 & 1995 & 2000 & 2005 & $2011^{1}$ \\
\hline \multicolumn{6}{|c|}{ Drinking Water } \\
\hline Urban & 89.4 & 93.0 & 94.6 & 95.0 & 96.2 \\
\hline Rural & 51.2 & 61.2 & 68.0 & 70.7 & 77.1 \\
\hline Total & 78.4 & 84.6 & 87.8 & 89.2 & 91.6 \\
\hline \multicolumn{6}{|c|}{ Sanitary service } \\
\hline Urban & 79.0 & 87.8 & 89.6 & 94.5 & 96.6 \\
\hline Rural & 18.1 & 29.6 & 36.7 & 57.5 & 69.2 \\
\hline Total & 61.5 & 72.4 & 76.2 & 85.6 & 90.2 \\
\hline \multicolumn{6}{|c|}{ Wastewater sewerage } \\
\hline Municipal & & & & & 46.5 \\
\hline
\end{tabular}

1. Preliminary data.

Source: CONAGUA (2011), SEMARNAT (2012).

Considering future population growth, in the next 20 years Mexico will need to provide an additional 36 million inhabitants with drinking water services and 40 million with sanitation services. In addition the 
efficiency and reliability of service provision as well as the financial sustainability of the service providers are major concerns (OECD, 2013b).

Water tariffs are extremely low for households, as in many cases they do not even reflect the operation and maintenance costs of providing the services and they have a zero VAT rate. On average, they are the lowest among OECD countries. Tariffs are proposed by each municipality and approved by the State Congress, but on average they cover only $45 \%$ of total costs, often do not keep up with inflation, and show great disparities (Figure 10). The result is an excessive dependence on federal and state resources. Investments are funded by federal transfers $(48 \%)$, state transfers $(18.5 \%)$ and private and bank loans $(20.5 \%)$, with only $12 \%$ financed by municipalities.

The inability to raise tariffs is related to the fact that an increase needs to be approved by the State Congress where the political cost of raising tariffs is high. An additional and large problem comes from low bill collection rates due to lack of incentives for municipalities to collect given that their budgets rely largely on federal and state transfers. These incentives will have to be addressed in line with the recommendations made in Chapter 3 of the 2013 Mexico Economic Survey (OECD, 2013d).

Figure 10. Water tariffs and tariffs by municipalities
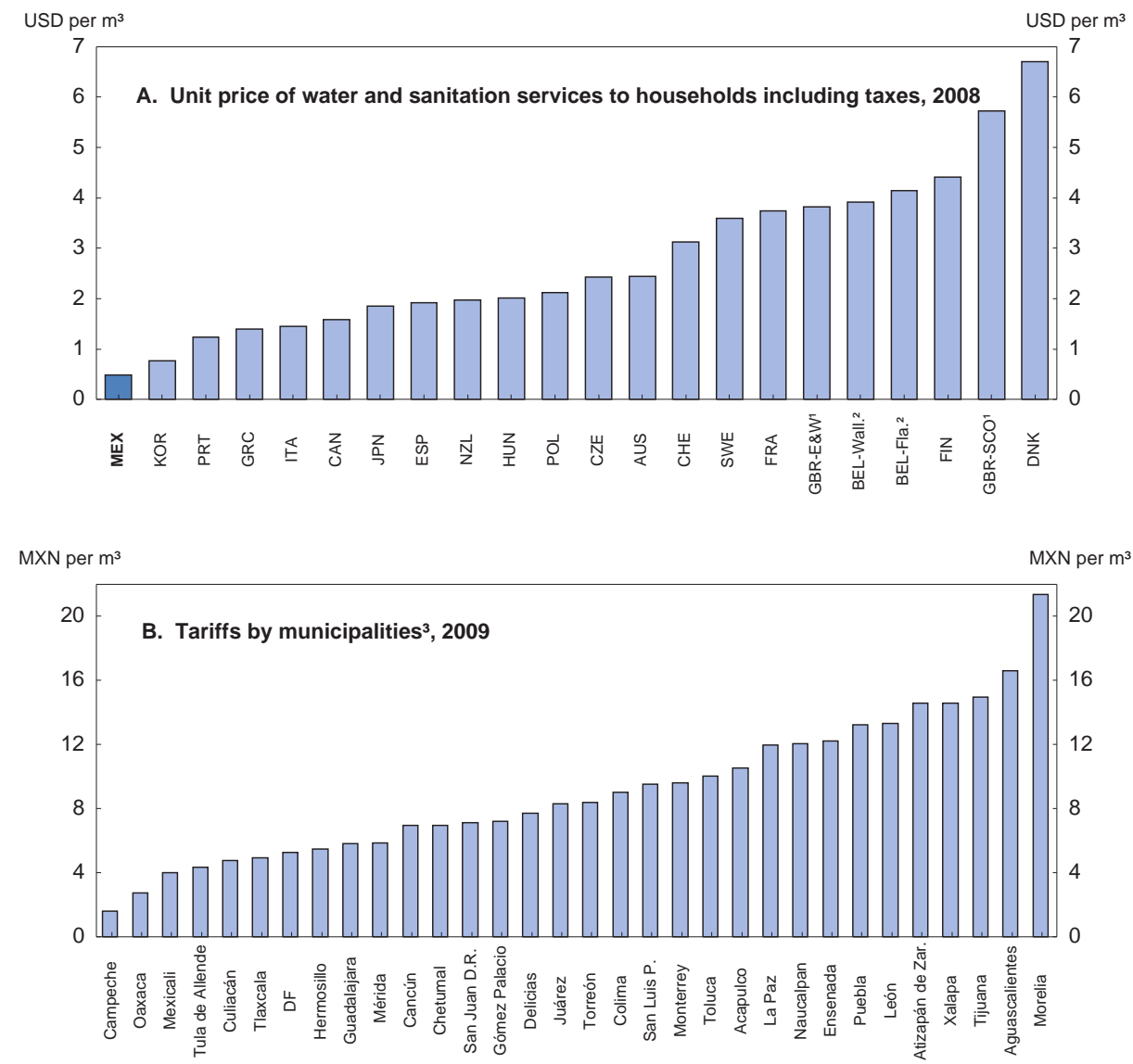

1. GBR-E\&W for England and Wales and GBR-SCOT for Scotland.

2. BEL-Wall for Walloon region and BEL-Fla. for Flemish region of Belgium.

3. Highest tariffs for a $30 \mathrm{~m}^{3}$ per month's consumption.

Source: OECD (2010), Pricing Water Resources and Water and Sanitation Services; CONAGUA. 
Tariffs need to be increased in a number of areas (OECD, 2013b). Prices for water services should reflect the operation and maintenance costs of providing the services. In most cases, though, a phased-in approach involving greater bill collection will be necessary to put utility balance sheets on a firmer footing and build consumer trust as a prerequisite to tariff increases (OECD, 2012b).

Recent OECD work on the 2030 Water Agenda highlights extensively a number of specific actions that could contribute to a cohesive and cost-efficient water policy framework to address the main problems in the water sector and achieve the objectives set in the Agenda (OECD, 2013b). The work focuses on improving multi-level governance issues to address territorial and institutional fragmentation of the water sector, strengthening river basin governance for effective integrated water resources management, improving the regulatory frameworks for water service provision, and enhancing the economic efficiency and financial sustainability of water policies. The main policy recommendations that emerge from this study in order to make the water reform happen are: $i$ ) develop a whole-of-government implementation action plan building on the 2030 Water Agenda, ii) set up mechanisms and incentives for enhancing water policy outcomes at different government and institutional levels, iii) fully exploit the benefits of existing economic instruments, design and implement charges, tariffs, other schemes and water markets in line with water policy objectives, increase tariff levels and change tariff structures to enhance efficient uses of water, iv) clarify the regulatory framework for water services, $v$ ) strengthen the role, prerogatives and autonomy of river basin councils and their auxiliary bodies, vi) establish a platform to share good practices, vii) foster transparency, information sharing and public participation in all relevant processes, and viii) evaluate the effectiveness of federal programmes at achieving water policy objectives.

\section{Green investment needs}

Investment needs for tackling climate change and addressing broader environmental challenges are considerable. In particular, investments in basic infrastructure need to be scaled-up significantly to meet development goals. While greening infrastructure investment is often considered as an additional cost, recent work by the OECD suggests that limiting climate change to two degrees (i.e. low carbon development) could be achieved at investment costs similar to those projected under business-as-usual, particularly if interactions between network infrastructure requirements are considered (CorfeeMorlot et al., 2012).

In Mexico, climate change related required interventions through 2030 have been estimated by the World Bank to reach around USD 64 billion (Johnson et al., 2010). They include investments in the oil and gas sector (cogeneration in PEMEX), electricity (wind farms), energy end-use sector (expansion of efficient energy programmes), transport (mass transportation) and forestry (avoiding deforestation) (Figure 11). 
Figure 11. Investments required to 2030 in low-carbon interventions in Mexico by sector Investments required: 64.5 USD billion

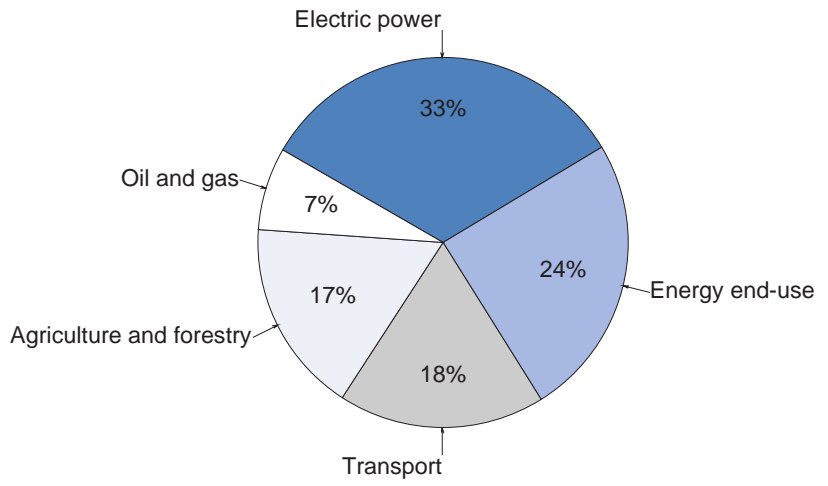

Source: Johnson et al. (2010).

In the water sector, CONAGUA estimates investments by 2030 of USD 83 billion in order to accomplish the water reform highlighted in its Water Agenda 2030 (CONAGUA, 2011). The goal is to meet demand for water in a sustainable way, achieve universal access to water and sanitation services, improve the water quality of rivers, lakes and aquifers, and to reduce exposure to hydro-meteorological events (Figure 12).

Figure 12. Investments required to implement the 2030 Water Agenda

Investments required: 83.1 USD billion

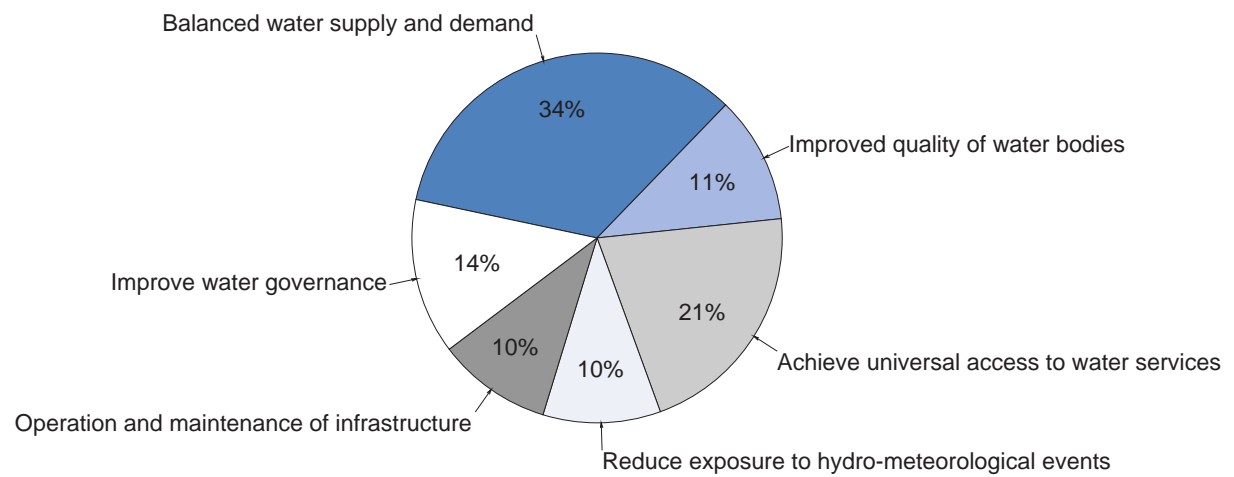

Source: CONAGUA (2011).

Alternative policy options such as removing environmentally harmful subsidies, pricing environmental goods and introducing carbon pricing could orient investment incentives in the right direction and open opportunities to finance green investments. However, the public sector will remain an important source of financing, as well as a facilitator for private sector investment, because infrastructure is often built for reasons of broader social well-being, or to offset remaining market failures. This is relevant, especially since there is insufficient infrastructure of high quality in terms of environmental impact with the corresponding negative effects on growth and well-being. Mexican development banks, mainly Banobras, and public infrastructure funds like the National Infrastructure Fund have been playing an 
important role in green infrastructure financing, either alone or by co-financing with the private sector. This includes wind energy projects, mass transit transportation and water service infrastructure. However, their role needs to become more efficient, including better planning, more cost-benefit analysis and better coordination between different government levels (see Chapter 3 of the 2013 Mexico Economic Survey) (OECD, 2013d).

The General Law on Climate Change establishes the creation of a Climate Fund for the collection and channelling of public and private resources (domestic and international) for mitigation and adaptation actions. These resources will be used, among other things, to purchase certified reductions of emissions and finance projects registered in the national emissions registry or approved by international agreements in which Mexico is part. Though this is only a starting point, progress has been made for the establishment of the fund with one billion MXP. The challenge ahead is to put institutions in place and clearly define the structure to channel these funds effectively and in a coordinated way with the institutions that currently carry these operations, such as development banks and infrastructure funds.

The Law on Climate Change also mandates the Federation, States and Federal District to design and implement economic instruments (fiscal, financial and/or market instruments) that promote compliance with the national climate-change policy goals. The Law lays out the technical and legal foundations to establish a national emissions trading system to encourage energy efficiency, including a regulating authority, and the possibility to establish emission trading agreements with other countries. This will facilitate and give more transparency to the financing of climate-change interventions.

Other key players in financing green infrastructure have been the multilateral development banks, such as the World Bank and the Inter-American Development Bank. However, given the scale of infrastructure investment needs, the private sector can potentially play a major role, but price incentives that give a reasonable return and changes in the regulatory regime are needed that address externalities, market imperfections, and specific investment barriers (Corfee-Morlot et al., 2012). Some examples are lowering the conditions to access the grid for private investors in renewable capacity, facilitating and promoting investment, and improving financing architecture and tools in the financial market. The introduction of the structured equity securities known as "CKDs" in 2008 was a strong step in this direction, since it has allowed private pension funds to invest in the infrastructure sector, including wind farms and water treatment plants (Box 1). CKDs can also include certain private equity, through which SMEs are expected to have access to capital markets. The adoption of the PPP Law (Ley de Asociaciones Público Privadas) in 2012 is another step towards enhancing private investment through public-private partnerships. However, potential benefits and risks of private financing should be carefully addressed, in particular when they require government guarantees, PPPs, involve future pensions or depend on more complex structured finance. 


\section{Box 1. Attracting private investment towards green infrastructure through structured instruments (CKDs)}

Infrastructure is a key factor in economic development and Mexico still lags in this area. The country's annual expenditure on infrastructure investment averaged 3.2\% of GDP between 2000 and 2006, compared to 5.8\% of GDP in Chile. The country stands in place 73 of 142 countries in terms of the quality of its infrastructure (WEF, 2012). This indicates a significant lag compared to other OECD countries and also if compared with peer economies in Latin America and other emerging countries. However, Mexico may have an opportunity to leap-frog other countries by introducing greener and more energy efficient infrastructure, including use of more sustainable energy sources and clean technology.

Though the public sector has increased resources for infrastructure investments, large capital needs led the previous government to make efforts to attract the private sector into financing infrastructure. One of the initiatives was to amend investment rules of private pension funds (AFORES) to allow them to invest in infrastructure related trust securities known as CKDs (Capital Development Certificates). In addition, the regulation allowed investment in Infrastructure and Real Estate Investment Trusts known as FIBRAS. These two products were designed so that the principal sources of capital came from institutional investors.

CKDs are securities issued by trusts on the Mexican Stock Exchange for a fixed period of time and with variable performance which can be partially or fully related to the underlying trust assets. These securities fund the development of infrastructure projects, housing and private equity. As of December $2012,27 \%$ of this issuance is related to infrastructure projects, $32 \%$ to housing and the rest to private equity (mostly small and medium size firms). In order to be eligible as CKDs, these instruments must meet some characteristics such as finance investment within national territory, comply with National Stock Exchange rules and projects must be approved by the issuing trust's technical committee. Since its value is tied to the performance of the project, returns come from the dividends or sales of shares.

Pension funds are the most important institutional investors in Mexico, with funds under management of more than USD 146 billion (12\% of GDP). For pension funds, infrastructure projects match their long term investment horizon, with steady inflation-adjusted income streams. Yet, despite this match of interests, it was not until 2000 that Mexican Pension Funds started to gradually invest in instruments other than government debt - following gradual changes in regulations - thus reducing their share from almost 98\% in 2000 to $54 \%$ in December 2012. Pension funds' asset allocation in infrastructure has been mainly indirectly thorough debt and equity instruments issued by private and public entities related to the sector. As of December 2012, around USD 4.5 billion of CKD's were issued and pension funds acquired $94 \%$ of them. Now, investment in CKDs represents $2.9 \%$ of total pension funds investment and $0.3 \%$ of GDP. Regulations allow them to invest up to $20 \%$ which gives them flexibility to keep increasing their asset allocation to infrastructure.

\section{Energy sector reform to boost the productivity of PEMEX}

The oil and gas sector, through the state-owned company PEMEX, plays a key role in Mexico's public finances, in its economy more broadly, and as a contributor to GHG emissions and environmental impact. PEMEX, one of the largest oil and gas producers in the world, contributes around a third of federal fiscal revenues - almost $8 \%$ of GDP - and is a major contractor of private sector goods and services. According to the Constitution, the State has exclusive rights to explore, exploit, refine and process crude oil and natural gas; produce basic petrochemicals and liquid petroleum gas; and carry out first-hand sales of such hydrocarbon products. Royalties and taxes applied mainly to its exploration and production subsidiary, represent $55 \%$ of sales. Crude oil production fell significantly from the mid-2000 to 2009 with the decline in the production of PEMEX's most important oil field Cantarell, only partly offset by increases in production from other fields, notably Ku-Maloob-Zaap (Figure 13). However, PEMEX faces complex governance and operational challenges, including operational inefficiencies, low labour productivity, large pension liabilities and the aging of specialized workforce. This results in three of its four subsidiaries making large and persistent financial losses. Thus, the company has been relying increasingly on external borrowing to finance its investments (Figure 14). 
Figure 13. PEMEX oil production by fields

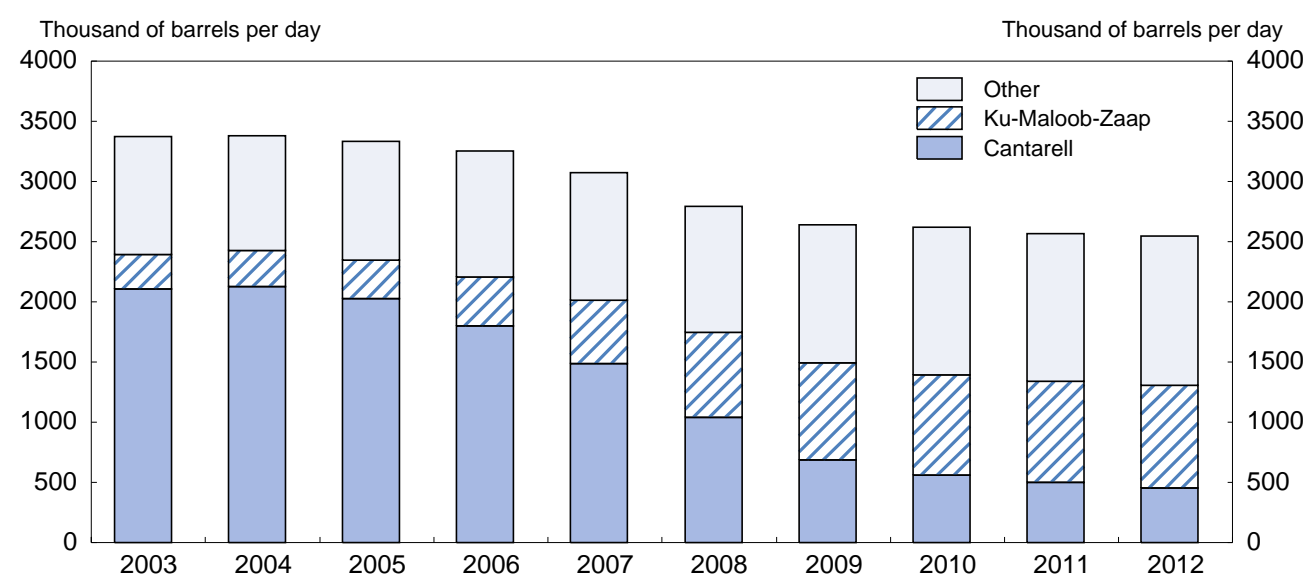

Source: PEMEX.

Figure 14. Financial summary of PEMEX'1

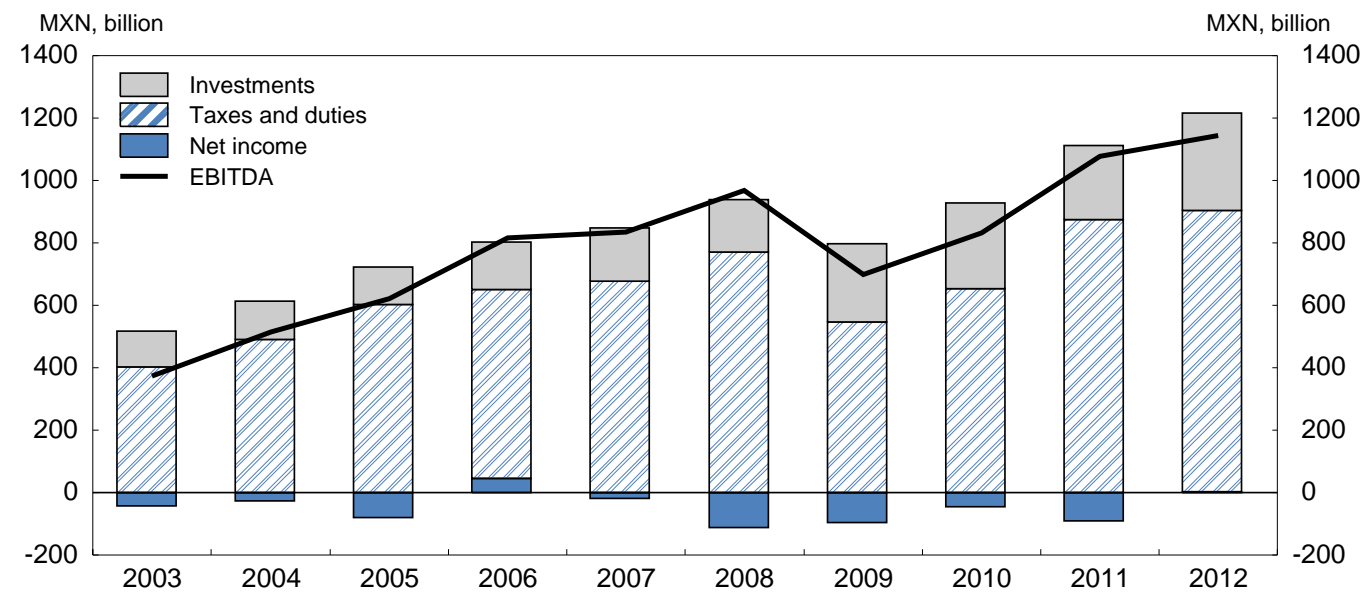

1. As of 31 December.

Source: PEMEX.

Improving operational efficiency, reforming the pension scheme and boosting the effectiveness of its investments, with the help of outside expertise, are needed to improve the results and performance of PEMEX. In addition, the technical oversight role of the National Hydrocarbons Commission should be strengthened.

The 2008 Energy Reform did not change the constitutional principles affecting PEMEX but enabled legal and structural changes, particularly in four areas: $i$ ) a special public administration regime authorized to adopt its own internal regulation and established the creation of value as an objective, ii) corporate governance reform granted the board greater authority over the company such as budget approval with some requirements, and broad-based improvements of corporate governance practices, iii) operational autonomy in financing and budget areas including the authority to obtain financing from external sources such as capital markets and bonds, and $i v$ ) a special contracting regime for procurement of goods and 
services, which allows the company to establish bid terms, criteria and contract models that best meet its needs as well as international market conditions (OECD, 2010).

The new rules clarified the company's objectives, furthered the scope for corporate governance reform, improved operational autonomy in financing and created a special contracting regime for procurement of goods and services (OECD, 2012a). The reform also gave PEMEX more autonomy and flexibility over contract models, with some successes. Yet, these reforms need to be pushed even further, including through a constitutional amendment that allows risk and profit sharing with the private sector. A more competitive environment for PEMEX would generate adequate market incentives to improve its efficiency, though regulation should be also widened to include oversight of new players. However, there is still room for allowing greater involvement of the private sector, by placing contract incentives such as using more than one variable to assign the contracts and modifying prequalification requirements to attract the participation of qualified partners that have the proven technical capability to exploit opportunities and to address environmental concerns. This becomes especially relevant if the company intends to develop deep-water and shale gas production (in particular in water-stressed areas), where environmental risks are especially high.

In August 2013, the government has presented a bill to Congress to reform the energy sector. The bill aims at changing the Constitution to allow for private sector participation in the energy and electricity sectors, while keeping the property of hydrocarbons under state control. It would allow for profit-sharing contracts in exploitation and exploration of oil and gas but would not allow the granting of concessions. In downstream (refining, petrochemical, transportation and retail of hydrocarbons), it would allow direct participation of private companies, through permits granted by the government. The proposal in general is a step in the right direction of opening the energy sector to private investment and promoting the use of private sector expertise in the oil and gas sector as well as improving PEMEX's operational and environmental efficiency and governance. However, much will depend on secondary laws and the ability of the government to offer attractive contracts in order to attract the participation of qualified partners.

Improving the financial situation of the company, along with new contracting models to bring frontier technologies and expertise will be essential to exploit opportunities to make profitable and greener investments. These include co-generation and energy efficiency, providing many unexploited investment opportunities for PEMEX, and the exploitation of the recent offshore deep-water discoveries (Trion 1 and Supremus 1) and of the abundant domestic shale gas and shale oil resources. Though all of this could increase PEMEX's production growth, its profitability and reserve volumes, such developments might prove challenging as the state-owned company will require significant new capital, outside expertise and good management of environmental risks associated with deep-water oil and shale gas. Moreover, facing a highly competitive unconventional gas industry in the United States, exploitation of shale gas will require low cost structures and a sufficiently attractive investment framework.

Given that Mexico's unconventional hydrocarbon resources are mostly located in the most waterconstrained regions of the country and unconventional gas production requires substantial amounts of water for hydraulic fracturing, the government would also have to further overhaul its water management and pricing system to make water allocation substantially more efficient than today, if it wanted to exploit these reserves taking into account social, economic and environmental costs. 
ECO/WKP(2013)87

\section{Box 2. Main recommendations for green growth and energy policy}

\section{Green growth}

- To ensure that the right price signals are provided, continue to remove fossil-fuel subsidies, and thereafter move towards carbon pricing.

- Shift towards a market-determined gasoline price with a positive excise tax, while using a transitory automatic smoothing mechanism.

- Restructure vehicle taxes to take into account environmental performance. Enforce environmental standards to encourage the use of more energy-efficient vehicles. Effectively direct public and private investment into mass transportation.

- Further strengthen energy efficiency and promote development of renewable energy by including social and environmental externalities into CFE's methodology for purchasing electricity at the least-cost price.

- Gradually remove electricity subsidies for residential users.

- Gradually remove electricity subsidies for pumping water for irrigation in agriculture and facilitate investment in water-efficient practices, including through cash transfers independent of water use.

- Raise water service tariffs to reflect operation and maintenance costs of providing services.

- Improve planning, fiscal relations between different government levels, and cost-benefit analysis to promote more efficient green infrastructure investment.

- Address externalities and promote private investment in renewables through setting right price signals, changes in the regulatory regime and reduced costs of access to the grid.

Energy reform

- Improve PEMEX's operational and environmental efficiency, and governance allowing much more reliance on private firms in the oil and gas sector so as to increase output and generate gains for the federal budget.

- $\quad$ Similarly, promote energy efficiency in CFE electricity operations, so as to reduce government subsidies and carbon emissions. Reduce PEMEX's environmental footprint.

- $\quad$ Promote the use of private sector expertise in oil and gas ideally by passing a constitutional amendment allowing risk sharing, or by at a minimum by and altering contract incentives to attract the participation of qualified partners with the proven capability to exploit opportunities.

- Further improve the corporate governance, transparency and autonomy of PEMEX. Strengthen the technical oversight role of the National Hydrocarbons Commission.

- $\quad$ Expand the scope of private capital to exploit deepwater and shale hydrocarbons. 


\section{BIBLIOGRAPHY}

CONAGUA (2011), 2030 Water Agenda, National Water Commission of Mexico, Mexico City.

Corfee-Morlot, J, V. Marchal, C. Kauffmann, C. Kennedy, F. Stewart, C. Kaminker and G. Ang (2012), "Towards a Green Investment Policy Framework: The Case of Low-Carbon, Climate-Resilient Infrastructure", OECD Environment Working Papers, No. 48, Paris.

Francke, E., J., Macías and G., Schmid (2012), "Mobilising Private Investment for Bus Rapid Transit Systems: The Case of Metrobus, Mexico City", draft case study prepared for the OECD by CTS EMBARQ Mexico City.

Hartley, P, and K. Medlock (2011), “The Revenue Efficiency of Pemex: A Comparative Approach”, The James Baker III Institute for Public Policy, Rice University, Houston, TX.

INEGI (2013), “Cuentas Económicas y Ecológicas de México 2007-2011”, Mexico City.

Johnson, T., C. Alatorre, Z. Romo and F. Liu (2010), Low-Carbon Development for Mexico, World Bank, Washington, DC.

OECD (2010), "Corporate Governance and Board Arrangements at Petróleos Mexicanos: Evaluation and Recommendations", www.pemex.com/index.cfm?action=content\&sectionid=127\&catid=14442.

OECD (2011a), OECD Economic Surveys: Mexico, Paris.

OECD (2011b), Environmental Performance Reviews: Portugal, Paris.

OECD (2012a), Public Procurement Review of PEMEX, Paris.

OECD (2012b), Framework Conditions for Private Sector Participation in Water Infrastructure in Mexico, Paris.

OECD (2012c), Environmental Outlook to 2050: the consequences of inaction, Paris.

OECD (2013a), Getting it Right: A Strategic Agenda for Reform in Mexico, Paris.

OECD (2013b), Making Water Reform Happen in Mexico, Paris.

OECD (2013c), Environmental Performance Reviews: Mexico 2013, Paris.

OECD (2013d), OECD Economic Surveys: Mexico, Paris

SEMARNAT (2009), “Programa Especial de Cambio Climático 2009-2012”, Mexico City.

SEMARNAT (2012), Sexto Informe de Labores, Mexico City.

World Bank (2011), Climate-Smart Agriculture: Increased Productivity and Food Security, Enhanced Resilience and Reduced Carbon Emissions for Sustainable Development, Washington DC.

WEF (2012), 2011-2012 Global Competitiveness Report, World Economic Forum. 


\section{WORKING PAPERS}

The full series of Economics Department Working Papers can be consulted at www.oecd.org/eco/workingpapers/

1094. From bricks to brains: increasing the contribution of knowledge-based capital to growth in Ireland (November 2013) by David Haugh

1093. China's March to Prosperity: Reforms to Avoid the Middle-Income Trap

(November 2013) by Vincent Koen, Richard Herd and Sam Hill

1092. Multi Factor Productivity with natural capital

(November 2013) by Nicola Brandt, Paul Schreyer and Vera Zipperer

1091. Growth-promoting policies and macroeconomic stability (forthcoming)

(October 2013) by Douglas Sutherland and Peter Hoeller

1090. Policies for inclusive urbanisation in China

(October 2013) by Vincent Koen, Richard Herd, Xiao Wang and Thomas Chalaux

1089. Fiscal devaluation - can it help to boost competitiveness?

(October 2013) by Isabell Koske

1088. How to achieve growth- and equity-friendly fiscal consolidation? A proposed methodology for instrument choice with an illustrative application to OECD countries

(October 2013) by Boris Cournède, Antoine Goujard and Álvaro Pina

1087. Improving school-to-work transition in New Zealand

(September 2013) by Alexandra Bibbee

1086. The agri-food situation and policies in Switzerland

(September 2013) by Peter Jarrett and Charlotte Moeser

1085. Japan's challenging debt dynamics

(August 2013) by Yvan Guillemette and Jan Strasky

1084. Transitions in and out of unemployment among young people in the Irish recession

(August 2013) by Elish Kelly, Seamus McGuinness, Philip O'Connell, David Haugh and Alberto González Pandiella

1083. Is there convergence of Russia's regions? Exploring the empirical evidence: 1995-2010

(August 2013) by Hartmut Lehmann and Maria Giulia Silvagni

1082. The benefits and costs of highly expansionary monetary policy

(August 2013) by Łukasz Rawdanowicz, Romain Bouis and Shingo Watanabe

1081. The effectiveness of monetary policy since the onset of the financial crisis

(August 2013) by Romain Bouis, Łukasz Rawdanowicz, Jean-Paul Renne, Shingo Watanabe and Ane Kathrine Christensen

1080. Responding to key well-being challenges in Austria

(August 2013) by Rauf Gönenç, Oliver Röhn, Christian Beer and Andreas Wörgötter 
1079. Austria's well-being goes beyond GDP

(August 2013) by Oliver Röhn, Rauf Gönenç, Christian Beer and Romina Boarini

1078. Improving fiscal federal relations for a stronger Mexico

(August 2013) by Aida Caldera Sánchez

1077. Deleveraging: challenges, progress and policies

(August 2013) by Romain Bouis, Ane Kathrine Christensen and Boris Cournède

1076. Policies to support sustainable long-term growth in New Zealand

(July 2013) by Calista Cheung

1075. Do structural policies affect macroeconomic stability?

(July 2013) by Volker Ziemann

1074. A simple fiscal stress testing model - case studies of Austrian, Czech and German economies (July 2013) by Ondra Kamenik, Zdenek Tuma, David Vavra and Zuzana Smidova

1073. Road connectivity and the border effect: evidence from Europe

(July 2013) by Henrik Braconier and Mauro Pisu

1072. Fiscal consolidation across government levels. Part 3: Intergovernmental grants, pro- or counter-cyclical?

(July 2013) by Hansjörg Blöchliger and Balázs Égert

1071. Fiscal consolidation across government levels. Part 2: Fiscal rules for sub-central governments, update of the institutional indicator

(July 2013) by Kaja Fredriksen

1070. Fiscal consolidation across government levels. Part 1: How much, what policies?

(July 2013) by Hansjörg Blöchliger

1069. Restructuring the electricity sector and promoting green growth in Japan

(June 2013) by Randall S. Jones and Myungkyoo Kim

1068. Labour market policies to promote growth and social cohesion in Korea

(June 2013) by Randall S. Jones and Satoshi Urasawa

1067. Education reform in Korea

(June 2013) by Randall S. Jones

1066. Belgium: enhancing the cost efficiency and flexibility of the health sector to adjust to population ageing

(June 2013) by Stéphane Sorbe

1065. Italy and the euro area crisis: securing fiscal sustainability and financial stability

(June 2013) by Oliver Denk 